\title{
Lip and Oral Cavity Cancer pT4a TNM Finding v8
}

National Cancer Institute

\section{Source}

National Cancer Institute. Lip and Oral Cavity Cancer pT 4a TNM Finding v8. NCI

Thesaurus. Code C132699.

Lip and oral cavity cancer with moderately advanced local disease. For lip: Tumor invades through cortical bone or involves the inferior alveolar nerve, floor of mouth, or skin of face (i.e., chin or nose). For oral cavity: T umor invades adjacent structures only (e.g., through cortical bone of the mandible or maxilla, or involves the maxillary sinus or skin of face). Note: Superficial erosion of bone/tooth socket (alone) by a ging ival primary is not sufficient to classify a tumor as T4. (from AJCC 8th Ed.) 